\title{
Article \\ Business Model Innovation Based on New Technologies and Its Influence on a Company's Competitive Advantage
}

\author{
Adam Dymitrowski ${ }^{1, *(D)}$ and Paweł Mielcarek ${ }^{2}$ (D) \\ 1 Department of International Marketing, Institute of International Business and Economics, Poznań University \\ of Economics and Business, al. Niepodległości 10, 61-875 Poznań, Poland \\ 2 Department of Organisation and Management Theory, Institute of Management, Poznań University of \\ Economics and Business, al. Niepodległości 10, 61-875 Poznań, Poland; pawel.mielcarek@ue.poznan.pl \\ * Correspondence: adam.dymitrowski@ue.poznan.pl
}

check for updates

Citation: Dymitrowski, A.; Mielcarek, P. Business Model Innovation Based on New

Technologies and Its Influence on a Company's Competitive Advantage. J. Theor. Appl. Electron. Commer. Res. 2021, 16, 2110-2128. https://doi.org/ $10.3390 /$ jtaer16060118

Academic Editor: Arcangelo Castiglione

Received: 19 July 2021

Accepted: 18 August 2021

Published: 22 August 2021

Publisher's Note: MDPI stays neutral with regard to jurisdictional claims in published maps and institutional affiliations.

Copyright: (c) 2021 by the authors. Licensee MDPI, Basel, Switzerland. This article is an open access article distributed under the terms and conditions of the Creative Commons Attribution (CC BY) license (https:// creativecommons.org/licenses/by/ $4.0 /)$.

\begin{abstract}
The aim of the paper is to determine the influence of BMI based on new technologies on a company's competitive advantage. In order to accomplish the aim a quantitative research was performed using the computer assisted telephone interview (CATI) method. There are two main outcomes of the research. Firstly, BMI based on new technologies has a positive influence on a company's competitive advantage. Secondly, it was proven that the greater the use of technologies for BMI the greater a company's competitive advantage is. Taking into account the research results, the paper explains how they contribute to the development of two theories- the theory of innovation as well the theory of competitive advantage. Several recommendations for business practice as well as policy makers are also formulated.
\end{abstract}

Keywords: business model innovation; new technology; competitive advantage

\section{Introduction}

How can companies build competitive advantage today? While globalization brings global opportunities such as access to foreign markets, it also brings global threats such as pandemics. Rivalry between companies is very strong and every company is looking for new ways to outperform competitors and ensure favorable market position.

Unexpectedly, a breath of fresh air has been pumped into the fierce competitive fight existing between companies. There were two reasons for this: firstly, the increasing interest in the phenomenon of business model innovation (BMI), which is considered a fundamentally different way of doing business within an existing one [1]; secondly, the fourth industrial revolution with its pool of innovative technologies called "new technologies". In this context it should be noted that innovative technologies are essential for businesses to stay competitive [2]. This has led to representatives of business practice seeing the potential and they have tried to combine their advantages by introducing BMI based on new technologies.

However, implementation of BMI is not an easy task [3]. As stated by [4],"BMI is of critical importance in the business environment of the fourth industrial revolution, yet such innovation is very difficult to achieve". Additionally, there is a dispute between researchers on the role played by BMI based on new technologies for a company's competitive advantage. Some authors, e.g., [5], believe that BMI based on new technologies have a positive impact on competitive advantage, but there are also those who think otherwise. For example, [2] stated that "changing the business model by introducing technological and sustainable components puts companies at high risk".

Having in mind these two contradictory stands within the literature on BMI based on new technologies and competitive advantage, the present authors decided to make an attempt to clear up existing doubts. The aim of the paper, therefore, is to determine the influence of BMI based on new technologies on a company's competitive advantage. 
In order to accomplish the paper's aim, two research methods were applied: critical analysis of the literature and empirical research in a quantitative form.

The reason to determine the influence of BMI based on new technologies on a company's competitive advantage is motivated by two facts. Firstly, the existing publications on BMI and new technologies tend to omit the possible synergic effects resulting from the use of few technologies at the same time. Existing literature (with some exceptions, e.g., [6]) tend to present the influence of specific technologies used for BMI purposes on a company's competitive advantage but omit to examine the effects of their joint utilization. Secondly, the existing literature identifies the effects of combining BMI with specific new technologies, but neglects to examine how these effects are reflected in company performance indicators. While the present study is aimed to fill up the existing gaps it should be seen as a relevant contribution to the research on BMI, new technologies and competitive advantages.

The paper consists of six sections. The literature review presents a critical review of existing research on BMI based on new technologies and competitive advantage. In this part of the paper an added value was provided by defining the current state of knowledge as well as identifying a research gap. In order to fill the existing research gap, two research hypotheses were formulated. The Materials and Methods section explains the adopted research perspective, gives detailed information on the research undertaken and the method of collecting data from primary sources. It also contains information describing the types of measures and statistical methods applied for the analysis. The Results section presents the outcomes of the performed analysis in the form of observations on the influence of BMI based on new technologies on a company's competitive advantage. Observations were supported with comments giving explanations for the reasons and causes for the present situation. The Discussion section compares the results obtained with existing research. It also discusses similar stances adopted by other research which supports the conclusions of the present paper. The Conclusions section presents the main outcomes of the study. It explains how the results enrich the current state of knowledge and develop the existing theoretical foundation. Recommendations for business practice representatives and policy makers are also formulated to aid them manage BMI based on new technologies and build competitive advantage of companies. The final two sections of the paper are acknowledgements and the list of references.

\section{Literature Review and Research Hypotheses Development}

Business model innovation has been a popular topic for some time. The increased research interest in BMI is represented by the dynamically increasing number of scientific publications touching on this subject. Although much attention has been paid to BMI, there is no consensus on a universal definition of the concept [4]. As stated by [7], BMI defines how a company creates and delivers value to customers and how it captures value. On the other hand, according to [8], BMI refers to how: "organizations transform new ideas into improved business models in order to advance, compete and differentiate themselves successfully in their marketplace". Both definitions suggest that BMI influences a company's competitive advantage. The more radical character of transformation and change, the more competitive a BMI is [2].

Additionally, some authors point out that BMI is defined as: "designed, novel, nontrivial changes to the key elements of a firm's business model and/or the architecture linking these elements" [9]. Such a definition underlines two aspects. Firstly, BMI is "designed" which means that it is a conscious and deliberate action undertaken by a company. It means that companies try to implement BMI with hope to influence a company's competitive advantage and outperform competitors. Although in the literature on innovation [10] a conscious and deliberate manner of creating innovation is believed to bring fruitful results again it has to be pointed out that successful implementation of BMI is difficult [2,3]. Secondly, the definition points out "elements" that need to be subjected to change. In the literature these "elements" can be seen from different perspectives, e.g., [4,11,12]. However, 
many researchers [13-15] point out that resources possessed by a company have a special place among different BMI elements.

When it comes to resources possessed by a company some authors [2,16] point out that technology can be used in order to deliver BMI. In this context it should be noted that not all researchers believe that technology plays a crucial role in creating BMI. One of the most famous (when it comes to number of citations-2006 already) publications on BMI is titled: "Business model innovation: it's not just about technology anymore" [17]. Therefore research which touches both on resources and BMI is divided into two streams. The first stream includes research which neglects the role of technology, concentrating on other, softer types of resources such as capabilities [18,19], knowledge [20] or intellectual capital [21]. However, the second stream contains research which proves that technology is an inseparable element of BMI and, as stated by [22,23], BMI and technology are interconnected. Authors associated with this stream believe that technology can not only help a company to deliver BMI [24], but that BMI can also result in technology creation $[25,26]$. The second stream of research is becoming increasingly important, because of the dynamic growth of what is called "new technologies". According to [3]: "new technologies are responsible for enabling new business models".

New technologies are defined as "any set of productive techniques which offers a significant improvement (whether measured in terms of increased output or savings in costs) over the established technology for a given process in a specific historical context. Defined thus, what is seen as 'new' is obviously subject to continual redefinition, as successive changes in technology are undertaken" [27]. With that in mind, it should be noted that even though new technologies are used by companies more often than ever before, it is difficult to find a classification of technologies which are supposed to be considered as "new". In this context, information provided by BCG [28] can be useful, which indicates that new technologies include: autonomous robots, simulation, integration of horizontal and vertical systems, Internet of Things, cyber security, cloud, additive production, augmented reality and Big Data. This classification was used by [29] who researched BMI based on new technologies. However, in a result of conducted qualitative study [29], enriched the classification provided by [28] and suggested to add artificial intelligence (AI), drones, electric vehicles and blockchain to the existing list of new technologies.

This present study, which concentrates on BMI based on new technologies, uses the classification suggested by [29]. There are three reasons for that. Firstly, the classification provided by [29] was published more recently than [28] which means that it offers a more up-to-date perspective. Secondly, it does not deny information suggested by [28] which is one of the most respected consulting companies in the world. On the contrary-it builds on BCG's classification. Thirdly, classification provided by [29] identifies thirteen instead of nine new technologies which enable adoption of broader research perspectives. Therefore, whenever the term "BMI based on new technologies" is mentioned in the paper, it refers to BMI which utilizes at least one of the technologies listed by [29].

In order to examine the phenomenon of competitive advantage of companies characterized with BMI based on new technologies, the present authors performed a critical analysis of literature. When reviewing the literature both EBSCO and ProQuest databases were searched for information. The reason for choosing these specific databases was the number of full text publications. Additionally, publications of globally respected consulting companies (such as BCG, Gartner, Forrester, EY, PWC and Deloitte) were taken into consideration. In order to be included in the literature review process a publication needed to meet three criteria: (1) touch on BMI, (2) touch on at least one of the new technologies from adopted classification, namely: autonomous robots, simulation, integration of horizontal and vertical systems, Internet of Things, cyber security, cloud, additive production, augmented reality and Big Data, drones, AI, electric vehicles and blockchain, (3) refer to competitive advantage. Results of performed literature review are presented from perspective of different types of new technologies. 
Concerning autonomous robots, they can modify the way a company operates in the market and enable BMI. According to Deloitte's report [30], there are certain advantages of autonomous robots, especially in reference to supply chain management that include among others reduction of costs, error rate and frequency of inventory checks, increased productivity as well as optimizing picking, sorting, and storing times. All these advantages strongly affect companies competitive advantages. Such a statement is supported by another consulting company Ernst\&Young [31], according to which robots are affecting the efficiency of companies operations in many areas from finance, human resources, and IT to customer care.

When it comes to simulation, analysts of Gartner believe that companies can use them in order to innovate the existing business model by enhancing the decision making process [32]. Companies representing different industries are using it to simulate realtime working conditions and perform intelligent decision-making and implement costeffective solutions [33]. In this context, it is worthy to mention a special type of simulation called digital twin (DT). They can simulate any aspect of companies operations. For example DTs can simulate the operation of a process or device (group of devices) on the basis of documentation which is aimed at eliminating any errors before implementing or building a physical device. According to Deloitte [34], DTs can increase efficiency in manufacturing, optimize supply chains, transform predictive field maintenance, and aid in traffic congestion remediation. Apart from digital twins, another use of simulationworth mentioning in reference to BMI is process replay in process mining. Process mining is analyzing current state of business process performance as well as identification of areas for improvement [35]. In this context, simulation can be used in order to represent possible improvements by replaying processes in different scenarios to identify ways of enhancing them.

When it comes to the integration of horizontal and vertical systems in the context of BMI and competitive advantage one should acknowledge that it refers both to upstream and downstream industry chains. It can serve as an effective way of gaining access to many types of resources which a company cannot possess when acting alone [36]. A BMI based on integration of horizontal and vertical systems often takes the form of a platform. Such a solution comes with specific advantages, e.g., sustainability or reduction of operational costs [37].

According to [4], BMI in the 21st century has to utilize such technologies as the Internet of Things (IoT) which enables companies to acquire information and communicate with physical products. Additionally, IoT allows the collection of real-time information from the physical world [38]. Real-time data in combination with historical data can be used to create the business models of tomorrow [39]. Thus, IoT equips companies with new tools motivating them to migrate from conventional product-centric approaches to digitallybased service-oriented approaches which results in BMI creation [40]. BMI based on IoT can reshape whole industries, e.g., the results of a study conducted by [41] suggest that IoT is an important factor causing retailers to innovate their business models. Moreover, Reference [42] points out that a dynamic increase in the implementation of BMI based on IoT is expected in the case of large manufacturing companies in the future.

When it comes to cyber security, BMI and competitive advantage, a few aspects should be pointed out. The first one is the rapid development of $5 \mathrm{G}$, which has a great potential for companies willing to deliver BMI, and cyber security that helps to exploit it [43]. The second aspect refers to the fact that cyber security ensures the proper implementation and use of BMI. This fact finds confirmation in the proved negative impact of cyber security breaches on innovative companies' business models. According to [44], cyber security breaches could decrease both a company's spending on R\&D and number of patents. Last but not least, cyber security helps to perform BMI and build competitive advantage by differentiating a company in a novel way [45].

When it comes to the cloud, it seems to be the type of new technology receiving the most research attention, as reflected in a high number of publications, e.g., [46-49]. 
According to [50], thanks to the cloud, companies can sense and seize opportunities in order to realign their business models and gain competitive advantage. In other words the cloud may set off a company's transformation process. It has to be pointed out, however, that innovating a business model is driven by a company's dynamic capabilities [48]. Where a company lacks dynamic capabilities, it might minimize the potential to use the cloud in order to create BMI and strengthen competitive advantage [50].

In the case of additive manufacturing, BMI and competitive advantage, it is believed that 3D printing technologies influence the way BMI is delivered. Three-dimensional (3D) printing supports the speed of prototype creation [51]. Therefore a company can act faster, test more solutions and better serve the needs of the market. BMI which uses $3 \mathrm{D}$ printing technologies are believed to result in a company's success as well as increase the firm's ability to survive in the market [52]. Furthermore, the scope of influence of BMI based on additive manufacturing is not just limited to single companies, but to many business entities. According to [53], it also affects entities engaged within supply chains.

When it comes to augmented reality (AR), Forrester's analysts [54] point out that it should be examined collectively with mixed reality (MR) and virtual reality (VR). AR is an interactive experience of a real-world environment where the objects are enhanced by computer-generated perceptual information [55]. MR, a related term, is the merging of real and virtual worlds to produce new environments, where physical and digital objects co-exist and interact in real time [56]. VR on the other hand is a computer-generated simulation (although VR is a type of simulation it was decided to discuss it in the context of AR; the reason for which is the similar nature of AR and VR, while both technologies refer to real-and-virtual combined environments called extended reality (XR)) in which a person can interact within an artificial environment [57]. According to [58], augmented technology will affect the manner of how companies do business by enabling BMI. It cannot only prolong product's life cycles but also increase companies competitiveness. Additionally, they fundamentally provide new methods of communication, learning and specialist training for companies which operate in specific industries [57].

The other technology which has been studied from the perspective of BMI and competitive advantage is Big Data. There are certain advantages for companies to implement Big Data. Firstly, it can be used to gather information regarding the market and customer behavior. Additionally, it enables a company to use real-time information and improve the decision-making process. Utilization of Big Data enhances the course of action involving strategic algorithms and procedures rather than simple use of managers' intuition [3]. Thus the company has a better understating of the market and greater ability to find market niches which can be targeted with BMI [59].

According to [7], the use of artificial intelligence (AI) has become a primary issue for business leaders considering BMI. The existing research on BMI, competitive advantage and AI concentrates on two forms of AI: machine learning and neural networks (deep learning). Results of the studies suggest that both forms of AI are speeding up BMI processes. The influence of AI on BMI is visible in three different aspects of interactions: between humans, humans and machines as well as between machines [60]. The last aspect seems to be of utmost importance while it suggests that BMI can be developed solely by machines, not engaging humans. Another interesting aspect is that AI can help to deliver green and sustainable BMI [61]. However, [7] points out that firms are struggling to make sense of the influence of $\mathrm{AI}$ and to come up with an appropriate AI strategy.

When it comes to drones, [62] states that they have become affordable enough to complement different types of businesses. Although drones are often considered as a new method of delivery, in the case of logistic solutions [63] they can also be used for different purposes such as collecting information [64]. According to the report by $\mathrm{PwC}$ [65], the usage of drones is becoming more and more popular in many industries. Additionally, drones can not only help to generate internal efficiencies of operations, but also create new revenue streams from a wide range of drone-related services. While these two aspects are important elements of companies business model, implementing drones can enable BMI. 
In the case of electric vehicles (EV), BMI and competitive advantage, the existing research points out the necessity to implement BMI. EV themselves are so innovative that they require new models of optimizing advertising, marketing and big data analysis to be provided in order to provide the most efficient way for companies to operate in the market [66]. Additionally, EV have the potential to challenge the existing business models of the automotive market and provide sustainability of not only the transportation system [67], but to make entire cities green [68]. When it comes to blockchain (BC), BMI and competitive advantage, it is believed to influence the manner in which companies manage value. According to [6], it has an impact on all three aspects of a company's value management, namely: value creation, delivery as well as capture, which results in BMI. Other authors [69], tend to share this point of view and state that blockchain could be a source of BMI. They also point out that it can result in delivering a sustainable BMI. In the case of hard data, BMI based on BC can reduce costs, help to deliver customized products and offer additional services [6].

A summary of existing research on BMI, new technologies and competitive advantage is presented in Table 1.

Table 1. Current state of knowledge on BMI based on new technologies and competitive advantage.

\begin{tabular}{|c|c|c|}
\hline Technology & Example References & Main Findings \\
\hline Autonomous robots & {$[30,31]$} & $\begin{array}{l}\text { - improve such areas of companies activity as supply chain, finance, } \\
\text { human resources, IT and customer care } \\
\text { - } \quad \text { help to reduce costs, error rate and frequency of inventory checks } \\
\text { increase productivity and efficiency of companies operations in } \\
\text { many areas }\end{array}$ \\
\hline Simulation & [32-34] & $\begin{array}{l}\text { - } \quad \text { simulate real-time working conditions } \\
\text { - } \quad \text { enhance decision making process } \\
\text { increase efficiency in manufacturing, optimize supply chains, transform } \\
\text { predictive field maintenance, aid in traffic congestion remediation }\end{array}$ \\
\hline $\begin{array}{l}\text { Integration of horizontal } \\
\text { and vertical systems }\end{array}$ & {$[36,37]$} & $\begin{array}{l}\text { - BMI based on integration of horizontal and vertical systems often takes } \\
\text { - } \quad \text { BMrm of a platform } \\
\text { to upstream and downstream industry chains }\end{array}$ \\
\hline Internet of Things (IoT) & [39-42] & $\begin{array}{l}\text { - } \quad \text { BMI based on IoT affects sales } \\
\text { - } \quad \text { use of IoT helps in building new business models } \\
\text { - } \quad \text { IoT affects BMI in different industries, e.g., retail industry } \\
\text { - } \quad \text { two main decision points can be identified in the BMI creation process } \\
\text { with the use of IoT: to test a BMI and scale it }\end{array}$ \\
\hline Cyber security & [43-45] & $\begin{array}{l}\text { - } \quad \text { helps to exploit } 5 \mathrm{G} \text { potential for BMI companies } \\
\text { - } \quad \text { cyber security enables successful BMI commercialization } \\
\text { cyber security breaches could decrease a company's spending on R\&D } \\
\text { and number of patents }\end{array}$ \\
\hline Cloud & [48] & $\begin{array}{l}\text { BMI based on cloud results in: improved flexibility, lower costs, } \\
\text { creation of new products, entrance to new markets } \\
\text { firms using BMI based on the cloud have to pass through several stages } \\
\text { (the process is iterative and non-linear) }\end{array}$ \\
\hline $\begin{array}{l}\text { Additive production (3D } \\
\text { printing) }\end{array}$ & {$[6,51-53]$} & $\begin{array}{l}\text { - } \quad \text { BMI based on additive production influence firm's success and } \\
\text { survival rate } \\
\text { - } \quad \text { BMI based on additive production reshape supply chains } \\
\text { - } 3 \text { D printing technologies influence the way BMI is delivered }\end{array}$ \\
\hline
\end{tabular}


Table 1. Cont.

\begin{tabular}{|c|c|c|}
\hline Technology & Example References & Main Findings \\
\hline Augmented reality & {$[54,57,58]$} & $\begin{array}{l}\text { - } \quad \text { Provide new ways of communication, learning and specialist training } \\
\text { - } \quad \text { Prolong product's lifecycles } \\
\text { - } \quad \text { Enables BMI creation }\end{array}$ \\
\hline Big Data & [3] & $\begin{array}{l}\text { - Big Data not only helps to deliver customer-driven products and } \\
\text { services, but also customer-driven BMI }\end{array}$ \\
\hline $\begin{array}{l}\text { Artificial intelligence } \\
\qquad(\mathrm{AI})\end{array}$ & {$[60,61]$} & $\begin{array}{l}\text { - AI within BMI is changing interactions between humans, humans and } \\
\text { machines and machines to machines } \\
\text { - } \quad \text { AI lowers the cost of prediction } \\
\text { - } \quad \text { AI can contribute to deliver sustainable BMI }\end{array}$ \\
\hline Drones & [62-65] & $\begin{array}{l}\text { - } \quad \text { help to generate internal efficiencies } \\
\text { - } \quad \text { create new revenue streams } \\
\text { - } \quad \text { ecame affordable for many companies } \\
\text { - } \quad \text { enable new services } \\
\text { enable BMI }\end{array}$ \\
\hline Electric vehicles (EV) & [66-68] & $\begin{array}{ll}\text { - } & \text { EV require BMI } \\
\text { - } & \text { EV in combination with BMI provide sustainability }\end{array}$ \\
\hline Blockchain (BC) & {$[6,69]$} & $\begin{array}{l}\text { blockchain helps companies overcome intellectual property and data } \\
\text { security barriers in implementing BMI } \\
\text { blockchain modifies the way companies create, deliver, and capture } \\
\text { value through BMI } \\
\text { blockchain could be a source of sustainable BMI }\end{array}$ \\
\hline
\end{tabular}

Source: compiled by the authors.

Two observations can be deduced from the information in Table 1. Firstly, research results presented in the literature tend to concentrate on identifying different effects of BMI based on new technologies which in turn influence competitive advantage. However, the existing studies neglect measuring competitive advantage gained through the effects of BMI based on new technologies. Secondly, most of the existing studies concentrate only on specific, single technologies applied for the purpose of performing BMI. However, with a few humble exceptions, e.g., [6], they do not acknowledge that companies can use multiple technologies at the same time. An example of such a situation is hyper automation, which combines technological advances of robotic process automation, enterprise application integration and artificial intelligence. The two observations deduced from the information in Table 1 represent an uncharted territory of BMI, new technologies and competitive advantage, and should be considered as a research gap.

The research gap is even more significant when one tries to correlate BMI based on new technologies to competitive advantage seen from the perspective of different performance indicators. The literature review revealed that the existing research focuses on the way BMI and new technologies influence competitive advantage, but little is known of the effects of such influence. Additionally, in the literature there is no consensus among researchers on the manner of BMI's influence on different company performance indicators [70]. Some authors [71,72] believe that BMI favors companies, but there are also those who state that BMI is not always beneficial $[73,74]$. Furthermore, according to [5] "few studies in the literature have addressed business model innovation, technological innovation, and their interplay towards a company's business performance, especially with empirical evidence". Even though some research exploring the influence of BMI based on specific technologies exist, they are too limited to make any general conclusions. For example, when taking into consideration the cloud, which has been characterized as a relatively well-studied aspect of BMI, in the literature it is still underlined that: "current research offers very limited insights on the / ... / use of cloud sourcing might trigger and push the development of business model innovation and affect the competitive advantage of a firm" [48]. This 
example is not the only one. The same situation occurs also in the case of the other relatively well-studied aspects of BMI, e.g., Big Data. As stated by [3] BMI, Big Data and competitive advantage are still poorly explored. The current state of knowledge in the area of BMI, new technologies and competitive advantage was well summed up by [5], who state that despite the significant potential, far too little attention has been devoted to these aspects.

Taking into consideration the significant research gap existing in the literature, the aim of the paper is to determine the influence of BMI based on new technologies on a company's competitive advantage.

In order to achieve the aim of the paper two research hypotheses have been formulated.

The first hypothesis (H1) states that: BMI based on new technologies positively influences a company's competitive advantage.

There are at least three reasons for supporting such a hypothesis. Firstly, although there are contradictory research results in the literature $[73,74]$ on the general role of BMI for competitive advantage, there are many authors, e.g., [75-77] who believe that BMI has a positive impact on a company. If so, BMI based on new technologies could also have a potential to positively influence competitive advantage. Secondly, the performed literature review (Table 1) identified many positive effects of different new technologies. According to the existing literature these positive effects should be reflected in company's competitive advantage. Thirdly, BMI helps companies to utilize technology [78]. Companies performing BMI or solely introducing "new technologies" may fail, whereas doing these simultaneously could bring fruitful results. This is because synergetic effects between BMI and "new technologies" are expected to occur, which in turn would positively influence the company's competitive advantage.

The second hypothesis (H2) states that: the more new technologies that are used for BMI, the greater a company's competitive advantage.

There are at least two reasons for supporting such a hypothesis. Firstly, as was already mentioned, the conducted literature review (Table 1 ) identified many positive effects of each of the discussed types of new technologies. With the introduction of each new type of technology, these effects should be collected and summarized. Therefore the more technologies a company characterized by BMI uses, the more positive effects and the greater impact on competitive advantage.

Secondly, the new technologies include 13 technologies [29] that differ greatly from each other. According to Gartner's report [79], it is more and more popular to combine different new technologies together. The more new technologies that companies characterized by BMI adopt, the more radical the character of innovation and greater impact on competitive advantage [24].

Taking into consideration the existing literature, a few boundary conditions for the two formulated research hypothesis can be identified. Some of them refer both to H1 and $\mathrm{H} 2$ (general boundary conditions) while others refer either to $\mathrm{H} 1$ or $\mathrm{H} 2$ (specific boundary conditions). One of the general boundary conditions refers to risk [80]. Because many BMI initiatives fail [81], both $\mathrm{H} 1$ and $\mathrm{H} 2$ assume that companies under investigation have reasons (e.g., BMI's market potential or company's differentiated fields of activity, etc.) to accept this risk. Another general boundary condition refers to market knowledge. While BMI is about a company creating and delivering new value to customers [7], it requires market knowledge [82]. Therefore, both $\mathrm{H} 1$ and $\mathrm{H} 2$ assume that market knowledge of companies under investigation is sufficient to create and deliver new value and perform BMI based on new technologies. When it comes to specific boundary conditions, they refer either to $\mathrm{H} 1$ or $\mathrm{H} 2$.

A specific boundary condition for $\mathrm{H} 1$ refers to companies internal absorption capabilities. Companies with well-developed internal absorption capabilities tend to do better than companies with underdeveloped internal absorption capabilities in terms of competitive advantage [83]. H1 assumes that companies under investigation have well developed internal absorption capabilities, otherwise they would neither implement BMI nor adapt new technologies. 
A specific boundary condition for $\mathrm{H} 2$ refers to an interplay between BMI and technology. According to [84], "technology's value comes from doing business differently because technology makes it possible". Such a statement points out a two-way relationship between BMI and technology. On one hand, BMI exploits the value of technology and helps companies deliver value, but on the other hand technology can be seen as a trigger for BMI. H2 assumes that the described interplay takes place in the case of companies characterized with BMI based on new technologies.

Achieving the aim of the paper and verifying the formulated research hypotheses will help to answer the question stated in the literature by [85]: "when does the combination of a novel technology and a novel business model lead to competitive advantages?".

\section{Materials and Methods}

In order to achieve the aim of the paper a quantitative study was undertaken. The reason for choosing a quantitative study was supported by the opinions of many authors, e.g., $[11,75]$, who underline the necessity to shift from qualitative research on BMI that is relatively popular to quantitative research, which is relatively rare.

Quantitative research was performed with the use of the Computer Assisted Telephone Interview (CATI) method. CATI was selected for a couple of reasons [86]. Firstly, it ensures a high response rate which makes the gathered data reliable. Secondly, it enables the possibility of answering questions or doubts which interviewees may raise during the interview. Thirdly, it helps to acquire data from hard-to-reach target groups (such as BMI companies). This method, therefore, helps to provide high-quality research data [87].

CATI was performed with the use of a standardized survey questionnaire. The questionnaire had questions referring to the research problem under investigation, such as type of technologies that the company utilizes or the company's competitive advantage. The company's competitive advantage was assessed from the perspective of performance indicators with the use of both financial and non-financial indicators on a 5-point Likert scale assessed in comparison with the company's competitors. This method of analysis is approved in the literature on innovation $[5,10]$.

In order to determine the optimal dimension of the research sample, except from considering the significance level, the total size of the population of Polish companies characterized by BMI based on new technologies should be taken into account. However, because of the unconventional character of companies characterized by BMI based on new technologies, obtaining such information is difficult. In light of difficulties with estimating the total size of the population of Polish companies characterized by BMI based on new technologies it was decided to use the convenience sample. Although the use of convenience sample has many advantages, e.g., being time and cost effective, it has to be pointed out that it also implies some limitations, the most important one being impossibility to generalize research results for the whole population [88]. A convenient research sample was selected from the Bisnod database, which consisted of 3500 companies. The size of the convenience research sample was estimated in order to ensure a reliable response rate. The research sample selection criteria included: using at least one of the new technologies (autonomous robots, simulation, integration of horizontal and vertical systems, Internet of Things, cyber security, cloud, additive production, augmented reality, Big Data, drones, AI, electric vehicles and blockchain), being located in Poland, providing contact information to representatives of top management. It means that contact information of the representatives of top management were listed in the database. While the authors intention was to perform CATI only with employees with wide knowledge about the company's activity, it was a criterion for research sample selection.

For the purpose of the study, top managers were selected as interviewees-CEOs, managing directors or senior managers with a background in areas crucial for the company's innovative activity, such as development, sales, purchase, finance, marketing, etc. Top managers were chosen as interviewees as it was necessary to obtain detailed information about the company's activity which was not limited to the competences of single 
departments, but rather the company as a whole because BMI refers to the manner of doing business which encompasses the whole company [89].

From 3500 companies, only those characterized with BMI were taken into consideration. In order to select companies characterized with BMI a filter question was asked: "Does your company have an innovative business model which means a novel and unique way of doing business?". The nature of the filter question was consistent with the essence of BMI definitions existing in the literature [7-9]. A positive answer to the filter question qualified a company to take part in the survey.

CATI research was performed in the period 8 January-14 January 2021. During that time, complete surveys were gathered from 483 companies, which constituted the research sample. The response rate was $12 \%$. The research sample characteristics are presented in Table 2.

Table 2. Research sample characteristics.

\begin{tabular}{|c|c|c|c|}
\hline & & Count & Table N \% \\
\hline \multirow{13}{*}{ Technologies } & autonomous robots & 94 & $19.5 \%$ \\
\hline & simulation & 160 & $33.1 \%$ \\
\hline & integration of horizontal and vertical systems & 110 & $22.8 \%$ \\
\hline & IoT & 181 & $37.5 \%$ \\
\hline & cyber security & 232 & $48.0 \%$ \\
\hline & cloud & 277 & $57.3 \%$ \\
\hline & additive production & 73 & $15.1 \%$ \\
\hline & augmented reality & 63 & $13.0 \%$ \\
\hline & Big Data & 134 & $27.7 \%$ \\
\hline & AI & 82 & $17.0 \%$ \\
\hline & electric vehicles & 47 & $9.7 \%$ \\
\hline & drones & 31 & $6.4 \%$ \\
\hline & blockchain & 21 & $4.3 \%$ \\
\hline \multirow{3}{*}{ Ownership } & local & 250 & $51.8 \%$ \\
\hline & international under local control & 79 & $16.4 \%$ \\
\hline & international under international control & 154 & $31.9 \%$ \\
\hline \multirow{4}{*}{ No. of employees } & $1-9$ & 96 & $19.9 \%$ \\
\hline & $10-49$ & 196 & $40.6 \%$ \\
\hline & 50-249 & 121 & $25.1 \%$ \\
\hline & 250 and more & 70 & $14.5 \%$ \\
\hline
\end{tabular}

Source: compiled by the authors.

For the purpose of the study, the same type of respondents (top managers of companies characterized with BMI based on new technologies) and five-point Likert scale were used, and so a common method bias might have arisen [90]. Thus, prior to data analysis, Harman's single-factor test was performed to address the potential issue of common method bias. For the purpose of the test, all the variables used for the study were subjected to factor analysis with the principal axis factoring method and unrotated factor solution in order to identify if one general factor accounts for more than $50 \%$ of the co-variation [91]. The results extracted one factor that accounted for $18.416 \%$ of the total variance. Therefore, the study is not affected by common method bias.

\section{Results}

In order to determine the influence of BMI based on new technologies on a company's competitive advantage a two-staged analysis was performed. The first stage of analysis verified whether BMI based on new technologies positively influences a company's competitive advantage. In order to accomplish this task, both financial and non-financial company performance indicators were considered and included: profit, sales, return on investments (ROI) and market share [10]. The four mentioned indicators have also been used by other authors to examine the role of BMI for a company's competitive advantage, e.g., profit and 
market share [5,7] or ROI and sales [5]. Use of competitive advantage indicators approved in the literature makes the results of the present study reliable. In order to determine the influence of BMI based on new technologies on a company's competitive advantage, respondents were asked to assess the four mentioned indicators in two periods: before introduction of BMI as well as after BMI's introduction. Comparing indicators before as well as after BMI's introduction enables to identify the change in time and determine not only the strength of influence but also the direction of change. The assessment was made by respondents in comparison with the company's competitors using the 5-point Likert scale (1-significantly worse, 2-worse, 3-no opinion, 4-better, 5-significantly better).The statistical significance of analysis was verified with a paired-samples $t$ test. The results of the analysis are presented in Table 3.

Table 3. Influence of BMI based on new technologies on competitive advantage.

\begin{tabular}{|c|c|c|c|c|c|c|c|c|}
\hline \multicolumn{9}{|c|}{ Paired Samples Statistics } \\
\hline & & & & Mean & $\mathbf{N}$ & \multicolumn{2}{|c|}{ Std. Deviation } & $\begin{array}{l}\text { Std. Error } \\
\text { Mean }\end{array}$ \\
\hline & \multirow{2}{*}{\multicolumn{3}{|c|}{$\begin{array}{l}\text { Profit before BMI } \\
\text { Profit after BMI }\end{array}$}} & 3.35 & 483 & \multirow{2}{*}{\multicolumn{2}{|c|}{$\begin{array}{l}0.703 \\
0.739\end{array}$}} & 0.032 \\
\hline Pair 1 & & & & 3.65 & 483 & & & 0.034 \\
\hline \multirow{2}{*}{ Pair 2} & \multirow{2}{*}{\multicolumn{3}{|c|}{$\begin{array}{l}\text { Sales before BMI } \\
\text { Sales after BMI }\end{array}$}} & 3.41 & 483 & \multirow{2}{*}{\multicolumn{2}{|c|}{$\begin{array}{l}0.738 \\
0.791\end{array}$}} & 0.034 \\
\hline & & & & 3.65 & 483 & & & 0.036 \\
\hline \multirow{2}{*}{ Pair 3} & \multirow{2}{*}{\multicolumn{3}{|c|}{$\begin{array}{c}\text { Market share before BMI } \\
\text { Market share after BMI }\end{array}$}} & 3.40 & 483 & \multirow{2}{*}{\multicolumn{2}{|c|}{$\begin{array}{l}0.746 \\
0.786\end{array}$}} & 0.034 \\
\hline & & & & 3.68 & 483 & & & 0.036 \\
\hline \multirow{2}{*}{ Pair 4} & \multirow{2}{*}{\multicolumn{3}{|c|}{$\begin{array}{l}\text { ROI before BMI } \\
\text { ROI after BMI }\end{array}$}} & 3.35 & 483 & \multirow{2}{*}{\multicolumn{2}{|c|}{$\begin{array}{l}0.731 \\
0.806\end{array}$}} & 0.033 \\
\hline & & & & 3.64 & 483 & & & 0.037 \\
\hline \multicolumn{9}{|c|}{ Paired Samples Test } \\
\hline & \multicolumn{5}{|c|}{ Paired Differences } & \multirow{3}{*}{\multicolumn{2}{|c|}{$\mathbf{t}$}} & \multirow{3}{*}{$\begin{array}{l}\text { Sig. } \\
\text { (2-Tailed) }\end{array}$} \\
\hline & \multirow{2}{*}{ Mean } & \multirow[t]{2}{*}{ Std. Deviation } & \multirow{2}{*}{ Std. Error Mean } & \multicolumn{2}{|c|}{$\begin{array}{c}\text { 95\% Confidence Interval } \\
\text { of the Difference }\end{array}$} & & & \\
\hline & & & & Lower & Upper & & & \\
\hline Pair 1 & -0.298 & 0.730 & 0.033 & -0.363 & -0.233 & -8.972 & 482 & 0.000 \\
\hline Pair 2 & -0.244 & 0.788 & 0.036 & -0.315 & -0.174 & -6.815 & 482 & 0.000 \\
\hline Pair 3 & -0.275 & 0.830 & 0.038 & -0.350 & -0.201 & -7.288 & 482 & 0.000 \\
\hline Pair 4 & -0.294 & 0.773 & 0.035 & -0.363 & -0.225 & -8.355 & 482 & 0.000 \\
\hline
\end{tabular}

Respondents' answers: 1-significantly worse, 2-worse, 3-no opinion, 4-better, 5-significantly better. Source: compiled by the authors.

Three observations can be deduced from the information in Table 3. Firstly, the means of all four company performance indicators differ before and after introduction of BMI by companies. The means of all four company performance indicators are higher after the introduction of BMI by companies in comparison to the time before the BMI's introduction. This fact reflects the positive influence of BMI on both profit as well as sales, ROI and market share. Secondly, the differences of means before and after introduction of BMI by companies in the case of all four company performance indicators are at a similar level $(0.25-0.3)$. On one hand, such a situation results from the small dispersion of possible answers caused by the use of the 5-point Likert scale. On the other hand it reflects a similar level of influence that BMI based on new technologies have on profit, sales, ROI and market share. Thirdly, the paired-samples $t$ test proved the statistical significance $(p<0.001)$ of the results for all four company performance indicators. These three observations justify stating that BMI based on new technologies positively influences a company's competitive advantage. Therefore, $\mathrm{H} 1$ is supported.

The second stage of analysis was used to verify whether a company has a greater competitive advantage when it uses more new technologies for BMI. In order to perform the analysis, companies characterized by BMI based on new technologies were divided 
into clusters using hierarchical cluster analysis with Ward's method for binary variables. The division criterion was the number of technologies used by companies. The squared Euclidean distance was taken as the measure of interval. The division into clusters was performed using a dendrogram. This led to the identification of three independent clusters of companies characterized by BMI based on new technologies. In order to compare the identified clusters in terms of the number of technologies used by companies, a Pearson's chi-squared test was carried out. The analysis showed significant differences between the identified clusters. The characteristics of the identified clusters are presented in Table 4.

Table 4. Clusters of companies characterized by BMI based on number of new technologies.

\begin{tabular}{|c|c|c|c|c|c|c|c|c|}
\hline & \multirow[b]{2}{*}{$\begin{array}{c}\text { No. of } \\
\text { Technologies }\end{array}$} & \multicolumn{4}{|c|}{ Size } & \multicolumn{3}{|c|}{ Ownership } \\
\hline & & Micro & Small & Medium & Big & Local & $\begin{array}{c}\text { International } \\
\text { under Local } \\
\text { Control }\end{array}$ & $\begin{array}{l}\text { International } \\
\text { under } \\
\text { International } \\
\text { Control }\end{array}$ \\
\hline Cluster $1(n=217)$ & $1-2$ & $34.6 \%$ & $42.9 \%$ & $18.0 \%$ & $4.6 \%$ & $66.4 \%$ & $12.9 \%$ & $20.7 \%$ \\
\hline Cluster $2(n=168)$ & $3-4$ & $10.1 \%$ & $42.3 \%$ & $29.2 \%$ & $18.5 \%$ & $41.7 \%$ & $17.9 \%$ & $40.5 \%$ \\
\hline Cluster $3(n=98)$ & $5-12$ & $4.1 \%$ & $32.7 \%$ & $33.7 \%$ & $29.6 \%$ & $36.7 \%$ & $21.4 \%$ & $41.8 \%$ \\
\hline
\end{tabular}

Source: compiled by the authors.

The information presented in Table 4 shows that the three identified clusters of companies characterized by BMI based on new technologies vary. Cluster 1 represents the use of 1-2 technologies and is dominated by micro (34.6\%) and small companies $(42.9 \%)$ and local form of ownership (66.4\%). Cluster 2 represents the use of 3-4 technologies and is dominated by small companies $(42.3 \%)$ and both local $(41.7 \%)$ and international under international control $(40.5 \%)$ form of ownership. Cluster 3 represents the use of 5-12 technologies and is dominated by companies bigger than micro and international under international control (41.8\%) form of ownership. When analyzing the different character of clusters one can observe a gradual shift from small local companies (cluster 1), towards big international under international control companies (cluster 3). Therefore the bigger and more international a company is, the higher the number of technologies utilized for BMI.

In order to compare performance indicators of the three identified clusters, a KruskalWallis $\mathrm{H}$ test was carried out. The results of the analysis are presented in Table 5.

Table 5. Results of Kruskal-Wallis H test.

\begin{tabular}{|c|c|c|c|c|c|c|c|}
\hline \multicolumn{8}{|c|}{ Ranks } \\
\hline & Clusters & $\mathbf{N}$ & Mean Rank & & Clusters & $\mathbf{N}$ & Mean Rank \\
\hline \multirow{4}{*}{ Profit } & 1 & 217 & 215.73 & \multirow{4}{*}{ Sales } & 1 & 217 & 200.95 \\
\hline & 2 & 168 & 242.20 & & 2 & 168 & 250.32 \\
\hline & 3 & 98 & 299.82 & & 3 & 98 & 318.65 \\
\hline & Total & 483 & & & Total & 483 & \\
\hline \multirow{4}{*}{ ROI } & 1 & 217 & 200.52 & \multirow{4}{*}{ Market share } & 1 & 217 & 213.29 \\
\hline & 2 & 168 & 249.67 & & 2 & 168 & 239.69 \\
\hline & 3 & 98 & 320.70 & & 3 & 98 & 309.55 \\
\hline & Total & 483 & & & Total & 483 & \\
\hline \multicolumn{8}{|c|}{ Test Statistics ${ }^{a, b}$} \\
\hline & & Profit & \multicolumn{2}{|c|}{ Sales } & ROI & \multicolumn{2}{|r|}{ Market Share } \\
\hline \multirow{2}{*}{\multicolumn{2}{|c|}{$\begin{array}{c}\text { Kruskal-Wallis H } \\
\text { df }\end{array}$}} & 29.541 & \multicolumn{2}{|c|}{56.891} & 59.102 & \multicolumn{2}{|r|}{37.868} \\
\hline & & 2 & \multicolumn{2}{|c|}{2} & 2 & \multicolumn{2}{|r|}{2} \\
\hline \multicolumn{2}{|c|}{ Asymp. Sig. } & 0.000 & \multicolumn{2}{|c|}{0.000} & 0.000 & \multicolumn{2}{|r|}{0.000} \\
\hline
\end{tabular}

\footnotetext{
${ }^{a}$ : Kruskal-Wallis Test; ${ }^{b}$ : grouping variable;clusters. Source: compiled by the authors.
} 
From the information presented in Table 5, it can be noted that there are statistically significant $(p m<0.001)$ differences between performance indicators of the three identified clusters. In terms of profit, companies from cluster 1 assessed this indicator significantly lower (215.73) than companies from cluster 2 (242.2). Similarly, companies from cluster 2 assessed profit significantly lower (242.2) than companies from cluster 3 (299.82). In terms of sales, companies from cluster 1 assessed this indicator significantly lower (200.95) than companies from cluster 2 (250.32). Similarly, companies from cluster 2 assessed sales significantly lower (250.32) than companies from cluster 3 (318.65). In terms of ROI, companies from cluster 1 assessed this indicator significantly lower (200.52) than companies from cluster 2 (249.67). Analogously, companies from cluster 2 assessed ROI significantly lower (249.67) than companies from cluster 3 (320.7). In terms of market share, companies from cluster 1 assessed this indicator significantly lower (213.29) than companies from cluster 2 (239.69). Analogously, companies from cluster 2 assessed market share significantly lower (239.69) than companies from cluster 3 (309.55). Having in mind that companies from cluster 1 use 1-2 technologies, companies from cluster 2 use 3-4 technologies and companies from cluster 3 use 5-12 technologies, it is justified to state that the more new technologies are used for BMI the greater a company's competitive advantage. Therefore $\mathrm{H} 2$ is supported.

While a company's competitive advantage is dependent on a great variety of determinants, BMI based on new technologies being just one of them, additional analysis were carried out in order to provide information supplementary to $\mathrm{H} 2$. It was decided to compare performance indicators of companies characterized by BMI based on new technologies of the same size (in terms on number of employees), form of ownership and operating in the same industry within the three identified clusters. Size, form of ownership and industry were chosen as common companies characteristics. However, it has to be stated that the delivered results were statistically insignificant. It means that delivered results should not be taken into consideration when providing conclusions from performed analysis. What is important is that the statistical insignificance of this supplementary information does not negate $\mathrm{H} 2$.

\section{Discussion}

When comparing the results of the present research with studies existing within the literature, a few aspects should be highlighted. Firstly, the present authors have proved the positive role played by BMI based on new technologies on a company's competitive advantage seen from the perspective of performance indicators. Such results are supported by [92], who believe that technology is the key to innovation. The results of the present paper are also consistent with the conclusions of [5], who empirically confirmed that technological innovation enhances BMI, and, in result, company's business performance.

Secondly, it is interesting to note that the results of the present study revealed the positive influence of BMI based on new technologies on all four company competitive advantage indicators: profit, sales, ROI as well as market share. Mean values of these indicators in all four cases showed advantage over competitors. While mean values express some generalization, it is justified to conclude that BMI based on new technologies is, in general, a guarantee of a company's competitive advantage. Such a statement is consistent with [17], who points out that commercialization of new technologies can be achieved through different business models.

Thirdly, an interesting tendency was observed where the bigger and more international a company is, the higher the number of technologies that are utilized for BMI. This observation is in contrast to the suggestion of [2], who believes that "medium-sized companies are more flexible, the decision-making process is quicker, and they can more easily adopt change-management strategies". The reason for bigger companies to utilize more technologies lies in the fact that they have more funds compared to other companies. Therefore big companies would more often invest in new technologies. Additionally, big companies often operate in international markets facing both international and local com- 
petition. Therefore they constantly need to search for new ways to distinguish themselves from market rivals. New technologies can help to achieve such an aim.

Fourthly, the results of the present study are in contradiction with the stream of research which focuses on the negative effects of BMI. For example, according to [81] "a high volume of initiatives related to BMI fail. In other words, even if these initiatives are in an ideal scenario [ ... ] it would still be difficult to achieve success in the implementation of such new BMs". The results of this study revealed that introducing BMI based on new technologies guarantees competitive advantage. The differences between the present authors' results and some other research concentrating on problems connected with BMI could be explained by the unique character of BMI based on new technologies. BMI based on new technologies is not a typical BMI. BMI itself is an innovation, but BMI based on new technologies is a combination of innovation. Therefore the character of BMI based on new technologies is very radical, which is the reason why it has such a positive influence on competitive advantage.

\section{Conclusions}

The aim of the paper was to determine the influence of BMI based on new technologies on a company's competitive advantage. The aim was achieved thanks to extensive (483 companies) empirical investigation carried out in the form of CATI. There are two main outcomes of the conducted research. Firstly, BMI based on new technologies has a positive influence on company's competitive advantage. Both financial and non-financial competitive advantage indicators (profit, sales, ROI and market share) were taken into account, and they all proved to be favorable in comparison to competitors for companies characterized by BMI based on new technologies. Secondly, it was proven that the greater the use of new technologies for BMI the greater the company's competitive advantage. Companies characterized by BMI based on new technologies were divided into three groups based on the number of technologies they utilize. Companies from the first group use the smallest number of technologies, companies from the second group use a slightly higher number of technologies, while companies from third group use the highest number of technologies. The observed tendency was very clear-competitive advantage indicators of companies from the third group were better compared to companies from both the first and second group, and the indicators of companies from the second group were better compared to companies from the first group.

The present results contribute significantly to the development of the current state of knowledge. This study is one of a few which examines the role of BMI based on new technologies on competitive advantage in a comprehensive manner. Existing studies (see Table 1) used to concentrate only on selected aspects of the research phenomenon referring to specific technologies. Additionally, as stated by [5], "despite its [technology and BMI] significance, only a limited set of research considered this when clarifying the relationships between innovation and a company's business success". The present study accurately fills the existing research gap by providing reliable (based on a relatively big research sample) results.

When acknowledging the present results, it should be noted that they significantly contribute to the development of at least two theories-theory of innovation as well theory of competitive advantage. When it comes to the theory of innovation, BMI based on new technologies should be seen as a new, unique form of innovation. It is a combination of two innovation types, namely an organizational and technological one. Being a mix of two types of innovation, BMI based on new technologies has a radical character. Therefore, when considering innovation, it takes the understanding of the scope of change, necessary to deliver a novel solution (innovation) into a new, unseen before level.

When it comes to the theory of competitive advantage, the results helped to identify a new method for companies that can be used in order to gain favorable (better than competitors) results. Mere adoption of BMI based on new technologies guarantees a competitive advantage for companies, but what is equally important is that developing BMI 
based on new technologies by implementing a higher number of new technologies further increases a company's competitive advantage. Therefore BMI based on new technologies seems to be a method with high potential among other methods mentioned by the theory of competitive advantage.

A few recommendations for business practice can be formulated from the results of the present study. Firstly, small and medium-sized companies (SMEs) should not feel constrained to perform BMI based on new technologies. The study revealed that this form of innovation is not reserved solely for big companies. On the contrary-even micro companies can adopt BMI based on new technologies. Secondly, companies utilizing four or fewer new technologies for the purpose of BMI should not stop there. Although the use of four innovative technologies may seem a lot, increasing the number of utilized technologies would further improve competitive advantage. Therefore, in order to maximize the positive effects of BMI based on new technologies for competitive advantage it is recommended to use at least five technologies. Thirdly, companies which are either characterized by BMI but do not use any new technologies or companies using new technologies which cannot be characterized as BMI companies and that obtain unsatisfactory results should consider converting into companies characterized by BMI based on new technologies. The results of the conducted research have revealed that these specific types of companies tend to obtain favorable performance indicators in comparison with market rivals.

Taking into consideration the results of the present study, a few recommendations for policy makers can also be formulated. Firstly, policy makers should promote BMI based on new technologies as a favorable development path for companies. While such a strategy leads to competitive advantage, policy makers should try to convince representatives of business practice to implement it. Promotion could take form of seminars and workshops for top managers who are the ones responsible for BMI's introduction in companies. Secondly, policy makers should award grants for companies to implement more new technologies for BMI purposes. Such grants should be targeted at two groups of companies (using 1-2 technologies and using 3-4 technologies) and aimed at using at least five new technologies (identified as the threshold of the most favorable number of technologies) for BMI purposes. Investments in use of more new technologies would result in better performance indicators of companies obtaining financial support.

Although the present authors made every possible effort to avoid potential research traps, the present study has certain limitations. One of these lies in the adopted classification of new technologies [29]. Although thirteen different types of new technologies were taken into consideration in the present study, one could argue that more types of new technologies exist. It means that results should be treated with some caution as they refer only to the selected new technologies. Additionally, one should consider results presented in the paper specifically from the perspective of the thirteen mentioned types of new technologies. The second limitation refers to the set of indicators used to assess competitive advantage. Although profit, sales, ROI and market share were used by other authors, e.g., [5] analyzing different performance indicators could have influenced the results. The third limitation refers to the division of companies into clusters. Although the division was statistically significant, it should be noted that the third cluster refers to a wide spectrum of technologies (5-12). In the case of the other clusters (first and second) the spectrum of utilized technologies was much narrower. Therefore competitive advantage indicators of the clusters need to be compared with some caution. The fourth limitation refers to defining the boundary conditions necessary for the truth of the hypothesis. In the paper authors proved statistical significance of $\mathrm{H} 1$ and $\mathrm{H} 2$. It means that incase of majority of companies BMI based on new technologies positively influence competitive advantage as well as in the case of majority of BMI companies with higher number of technologies the competitive advantage is greater compared to companies with lower number of technologies. It has to be however pointed out that these are just two general tendencies which are not true for every single company. In order for them to be true a set of conditions needs to be met. Although these conditions were not part of the research 
problem under investigation in the paper, the authors fully acknowledge their importance. It is more than probable that these conditions, at least to some extent, determined the results presented in the paper. The fifth limitation refers to the research method which was a quantitative analysis. This limitation was well visible in an attempt to compare performance indicators of companies characterized with the same size, form of ownership and operating in the same industry within the three identified clusters because the delivered results were statistically insignificant. Using a different (e.g., qualitative method) could deliver more fruitful results.

There are still many unknowns when discussing BMI based on new technologies and a company's competitive advantage. An interesting direction for future research could be to identify the conditions under which BMI based on new technologies succeed and fail. This recommendation for future research goes along with defining the boundary conditions which was identified as one of paper's limitations. Another possibility would be to compare performance indicators of companies characterized by BMI based on new technologies and which are divided into clusters in a different manner. Instead of taking into account the number of utilized technologies, one could try to identify clusters of companies characterized by BMI based on new technologies, having in mind their true occurrence in business practice. Additionally, while quantitative analysis could omit some nuances of the research phenomenon, in the future it is recommended to perform a qualitative analysis in order to examine the influence of companies size, form of ownership and industry on competitive advantage of companies characterized with BMI based on new technologies. Performing a qualitative analysis could also help to identify other determinants of competitive advantage of companies characterized with BMI based on new technologies. Following the suggested directions for future research would help to better understand the influence of BMI based on new technologies on competitive advantage.

Author Contributions: Conceptualization, A.D. and P.M.; Data Curation, A.D. and P.M.; Formal Analysis, A.D. and P.M.; Funding Acquisition, A.D. and P.M.; Investigation, A.D. and P.M.; Methodology, A.D. and P.M.; Project Administration, A.D.; Resources, A.D. and P.M.; Software, A.D. and P.M.; Supervision, A.D.; Validation, A.D. and P.M.; Visualization, A.D. and P.M.; Writing-Original Draft, A.D. and P.M.; Writing-Review and Editing, A.D. and P.M. All authors have read and agreed to the published version of the manuscript.

Funding: The project financed within the Regional Initiative for Excellence programme of the Minister of Science and Higher Education of Poland, years 2019-2022, grant no. 004/RID/2018/19, financing 3,000,000 PLN.

Conflicts of Interest: The authors declare no conflict of interest.

\section{References}

1. Markides, C. Disruptive Innovation: In Need of Better Theory*. J. Prod. Innov. Manag. 2006, 23, 19-25. [CrossRef]

2. Tohãnean, D.; Buzatu, A.I.; Baba, C.-A.; Georgescu, B. Business model innovation through the use of digital technologies: Managing risks and creating sustainability. Amfiteatru Econ. 2020, 22, 758-774. [CrossRef]

3. Minatogawa, V.L.F.; Franco, M.M.V.; Rampasso, I.S.; Anholon, R.; Quadros, R.; Durán, O.; Batocchio, A. Operationalizing Business Model Innovation through Big Data Analytics for Sustainable Organizations. Sustainability 2020, 12, 277. [CrossRef]

4. Van Tonder, C.; Schachtebeck, C.; Nieuwenhuizen, C.; Bossink, B. A framework for digital transformation and business model innovation. Manag. J. Contemp. Manag. Issues 2020, 25, 111-132. [CrossRef]

5. Smajlović, S.; Umihanić, B.; Turulja, L. The Interplay of Technological Innovation and Business Model Innovation toward Company Performance. Manag. J. Contemp. Manag. Issues 2019, 24, 63-79. [CrossRef]

6. Kloeckner, M.; Kurpjuweit, S.; Velu, C.; Wagner, S.M. Does Blockchain for 3D Printing Offer Opportunities for Business Model Innovation? Res. Technol. Manag. 2020, 63, 18-27. [CrossRef]

7. Katsamakas, E.; Pavlov, O. AI and Business Model Innovation: Leverage the AI Feedback Loops. J. Bus. Models 2020, 8, 22-30. [CrossRef]

8. Eppler, M.J.; Hoffmann, F. Challenges and Visual Solutions for Strategic Business Model Innovation. In Strategies and Communications for Innovations: An Integrative Management View for Companies and Networks; Hülsmann, M., Pfeffermann, N., Eds.; Springer: Berlin/Heidelberg, Germany, 2011; pp. 25-36. ISBN 978-3-642-17223-6.

9. Foss, N.J.; Saebi, T. Fifteen Years of Research on Business Model Innovation: How Far Have We Come, and Where Should We Go? J. Manag. 2016, 43, 200-227. [CrossRef] 
10. Dymitrowski, A. The Role of Innovations Created in the Internationalization Process for Company Performance; Wydawnictwo Naukowe PWN: Warszawa, Poland, 2014.

11. Clauss, T. Measuring Business Model Innovation: Conceptualization, Scale Development, and Proof of Performance. RED Manag. 2017, 47, 385-403.

12. Osterwalder, A.; Pigneur, Y. Business Model Generation: A Handbook for Visionaries, Game Changers, and Challengers; John Wiley \& Sons, Inc.: Hoboken, NJ, USA, 2010.

13. Bucherer, E.; Eisert, U.; Gassmann, O. Towards Systematic Business Model Innovation: Lessons from Product Innovation Management. Creat. Innov. Manag. 2012, 21, 183-198. [CrossRef]

14. Lopez, F.J.D.; Bastein, T.; Tukker, A. Business Model Innovation for Resource-Efficiency, Circularity and Cleaner Production: What 143 Cases Tell Us. Ecol. Econ. 2019, 155, 20-35. [CrossRef]

15. Rodriguez, R.; Molina-Castillo, F.-J.; Svensson, G. Enterprise Resource Planning and Business Model Innovation: Process, Evolution and Outcome. Eur. J. Innov. Manag. 2020, 23, 728-752. [CrossRef]

16. Cautela, C.; Pisano, P.; Pironti, M. The Emergence of New Networked Business Models from Technology Innovation: An Analysis of 3-D Printing Design Enterprises. Int. Entrep. Manag. J. 2014, 10, 487-501. [CrossRef]

17. Chesbrough, H. Business Model Innovation: It's Not Just about Technology Anymore. Strategy Leadersh. 2007, $35,12-17$. [CrossRef]

18. Lawson, B.; Samson, D. Developing Innovation Capability In Organisations: A Dynamic Capabilities Approach. Int. J. Innov. Manag. 2001, 5, 377-400. [CrossRef]

19. Najmaei, A.; Alhumdan, E.; Behnia, M. Bridging the Gap between Agility and Performance: The Role of Business Model Innovation. In Academy of Management Annual Meeting Proceedings; Academy of Management: Briarcliff Manor, NY, USA, 2017; Volume 2017.

20. Zheng, J.; Qiao, H.; Zhu, X.; Wang, S. Knowledge-Driven Business Model Innovation through the Introduction of Equity Investment: Evidence from China's Primary Market. J. Knowl. Manag. 2021, 25, 251-268. [CrossRef]

21. Elia, G.; Lerro, A.; Passiante, G.; Schiuma, G. An Intellectual Capital Perspective for Business Model Innovation in TechnologyIntensive Industries: Empirical Evidences from Italian Spin-Offs. Knowl. Manag. Res. Pract. 2017, 15, 155-168. [CrossRef]

22. Amit, R.; Zott, C. Value Creation in E-Business. Strateg. Manag. J. 2001, 22, 493. [CrossRef]

23. Teece, D.J. Business Models, Business Strategy and Innovation. Long Range Plan. 2010, 43, 172-194. [CrossRef]

24. Souto, J.E. Business Model Innovation and Business Concept Innovation as the Context of Incremental Innovation and Radical Innovation. Tour. Manag. 2015, 51, 142-155. [CrossRef]

25. Tavassoli, S.; Bengtsson, L. The Role of Business Model Innovation for Product Innovation Performance. Int. J. Innov. Manag. 2018, 22, 1850061. [CrossRef]

26. Wei, Z.; Yang, D.; Sun, B.; Gu, M. The Fit between Technological Innovation and Business Model Design for Firm Growth: Evidence from China. RED Manag. 2014, 44, 288-305. [CrossRef]

27. Marshall, G. New Technology. In A Dictionary of Sociology; Oxford University Press: Oxford, UK, 2021.

28. BCG Embracing Industry 4.0 and Rediscovering Growth. Available online: https://www.bcg.com/capabilities/operations/ embracing-industry-4.0-rediscovering-growth (accessed on 1 October 2020).

29. Dymitrowski, A.; Mielcarek, P. Business Model Innovation Based on New Technologies and Companies Behavior. In Proceedings of the 3rd Economics, Business and Organization Research (EBOR) Conference, Rome, Italy, 20-22 November 2020.

30. Deloitte. Using Autonomous Robots to Drive Supply Chain Innovation; Deloitte: New York, NY, USA, 2017.

31. Ernst\&Young Intelligent Automation. Available online: https://www.ey.com/en_gl/intelligent-automation (accessed on 12 August 2021).

32. Sun, D.; Tyler, I. The Gartner Business Model Innovation Framework: A Tool for Deciphering High-Impact Digital Initiatives; Gartner: Stamford, CT, USA, 2021.

33. Lim, K.Y.H.; Zheng, P.; Chen, C.-H. A State-of-the-Art Survey of Digital Twin: Techniques, Engineering Product Lifecycle Management and Business Innovation Perspectives. J. Intell. Manuf. 2020, 31, 1313-1337. [CrossRef]

34. Deloitte. Tech Trends 2020; Deloitte: New York, NY, USA, 2020.

35. Martin, N.; Depaire, B.; Caris, A. The Use of Process Mining in Business Process Simulation Model Construction: Structuring the Field. Bus. Inf. Syst. Eng. 2016, 58, 73-87. [CrossRef]

36. Peng, B.; Fang, H.; Zhang, F. Vertical Integration the Business Model Innovation of the Lithium Ion Battery Industry; Wang, H., Takahashi, K., Eds.; Beihang Univ. Press: Beijing, China, 2014; pp. 471-475, ISBN 978-7-5124-1392-4.

37. Sandoval, M.; Grijalva, S. Future Grid Business Model Innovation: Distributed Energy Resources Services Platform for Renewable Energy Integration; Monsalve, C., Sanchez, A., Chaczko, Z., Eds.; IEEE: New York, NY, USA, 2015; pp. 72-77, ISBN 978-1-4799-7588-4.

38. De Souza, C.A.; Szafir-Goldstein, C.; Aagaard, A. IoT in the Context of Digital Transformation and Business Model Innovation: The Case of a Traditional Brazilian Wholesaler; IEEE: New York, NY, USA, 2020; ISBN 978-1-72816-728-2.

39. Aagaard, A.; Presser, M.; Beliatis, M.; Mansour, H.; Nagy, S. A Tool for Internet of Things Digital Business Model Innovation. In 2018 Ieee Globecom Workshops (gc Wkshps); IEEE: New York, NY, USA, 2018; ISBN 978-1-5386-4920-6.

40. Paiola, M.; Gebauer, H. Internet of Things Technologies, Digital Servitization and Business Model Innovation in BtoB Manufacturing Firms. Ind. Mark. Manag. 2020, 89, 245-264. [CrossRef] 
41. Nosratabadi, S.; Mosavi, A.; Lakner, Z. Food Supply Chain and Business Model Innovation. Foods 2020, 9, 132. [CrossRef] [PubMed]

42. Tesch, J.F.; Brillinger, A.-S.; Bilgeri, D. Internet of things business model innovation and the stage-gate process: An exploratory analysis. Int. J. Innov. Manag. 2017, 21, 1740002. [CrossRef]

43. Lindgren, P.; Wuropulos, K. Secure Persuasive Business Models and Business Model Innovation in a World of 5G. Wirel. Pers. Commun. 2017, 96, 3569-3583. [CrossRef]

44. He, C.Z.; Frost, T.; Pinsker, R.E. The Impact of Reported Cybersecurity Breaches on Firm Innovation. J. Inf. Syst. 2019, 34, 187-209. [CrossRef]

45. Kosutic, D.; Pigni, F. Cybersecurity: Investing for Competitive Outcomes. J. Bus. Strategy 2020. ahead-of-print. [CrossRef]

46. Berman, S.J.; Kesterson-Townes, L.; Marshall, A.; Srivathsa, R. How Cloud Computing Enables Process and Business Model Innovation. Strategy Leadersh. 2012, 40, 27-35. [CrossRef]

47. Brook, J.W.; Feltkamp, V.; van Der Meer, M. Cloud Enabled Business Model Innovation: Gaining Strategic Competitive Advantage as the Market Emerges. In Proceedings of the ISPIM Conferences; The International Society for Professional Innovation Management (ISPIM): Manchester, UK, 2012; pp. 1-16.

48. Muhic, M.; Bengtsson, L. Dynamic Capabilities Triggered by Cloud Sourcing: A Stage-Based Model of Business Model Innovation. Rev. Manag. Sci. 2021, 15, 33-54. [CrossRef]

49. Nieuwenhuis, L.J.M.; Ehrenhard, M.L.; Prause, L. The Shift to Cloud Computing: The Impact of Disruptive Technology on the Enterprise Software Business Ecosystem. Technol. Forecast. Soc. Chang. 2018, 129, 308-313. [CrossRef]

50. Bouncken, R.B.; Kraus, S.; Roig-Tierno, N. Knowledge- and Innovation-Based Business Models for Future Growth: Digitalized Business Models and Portfolio Considerations. Rev. Manag. Sci. 2021, 15, 1-14. [CrossRef]

51. Rayna, T.; Striukova, L. From Rapid Prototyping to Home Fabrication: How 3D Printing Is Changing Business Model Innovation. Technol. Forecast. Soc. Chang. 2016, 102, 214-224. [CrossRef]

52. Rayna, T.; Striukova, L. Adaptivity and Rapid Prototyping: How 3D Printing Is Changing Business Model Innovation. In 3D Printing: Legal, Philosophical and Economic Dimensions; Van Den Berg, B., Van Der Hof, S., Kosta, E., Eds.; T.M.C. Asser Press: JN Den Haag, The Netherlands, 2016; Volume 26, pp. 167-182. ISBN 978-94-6265-096-1.

53. Ji, S.; ran Jin, Y. Business model innovation under the background of 3d printing: Supply chain perspective. J. Investig. Med. 2014, 62, S115-S116.

54. Miller, P. Extended Reality Will Help Manufacturers with More Than Just Training and Remote Assistance; Forrester: Cambridge, MA, USA, 2019.

55. Ariso, J.M. Augmented Reality: Reflections on Its Contribution to Knowledge Formation; Berlin Studies in Knowledge Research; De Gruyter: Berlin, Germany, 2017; ISBN 978-3-11-049700-7.

56. Ercan, F. An Examination on the Use of Immersive Reality Technologies in the Travel and Tourism Industry. Bus. Manag. Stud. Int. J. 2020, 8, 2348-2383. [CrossRef]

57. Kulkov, I.; Berggren, B.; Hellström, M.; Wikström, K. Navigating Uncharted Waters: Designing Business Models for Virtual and Augmented Reality Companies in the Medical Industry. J. Eng. Technol. Manag. 2021, 59, 101614. [CrossRef]

58. Gruia, L.-A.; Bibu, N.; Nastase, M.; Roja, A.; Cristache, N. Approaches to Digitalization within Organizations. Rev. Int. Comp. Manag./Rev. Manag. Comp. Int. 2020, 21, 287-297.

59. Bouwman, H.; Nikou, S.; de Reuver, M. Digitalization, Business Models, and SMEs: How Do Business Model Innovation Practices Improve Performance of Digitalizing SMEs? Telecommun. Policy 2019, 43, 101828. [CrossRef]

60. Valter, P.; Lindgren, P.; Prasad, R. Advanced Business Model Innovation Supported by Artificial Intelligence and Deep Learning. Wirel. Pers. Commun. 2018, 100, 97-111. [CrossRef]

61. Weiss, P.V.; Scheiblich, M.; Buzatu, A.-I.; Costache, I.C. Green business model innovation: Enhancing business processes through application of artificial intelligence in order to reduce the ecological footprint. In Proceedings of the 2019 BASIQ International Conference: New Trends in Sustainable Business and Consumption, Bari, Italy, 30 May-1 June 2019; Dinu, V., Ed.; Editura ASE: Bucuresti, Romania, 2019; pp. 704-710.

62. Kumar, A.; Muhammad, B. On How Internet of Drones Is Going to Revolutionise the Technology Application and Business Paradigms. In Proceedings of the 2018 21st International Symposium on Wireless Personal Multimedia Communications (WPMC), Chiang Rai, Thailand, 25-28 November 2018; pp. 405-410.

63. Vlahovic, N.; Knezevic, B.; Batalic, P. Implementing Delivery Drones in Logistics Business Process: Case of Pharmaceutical Industry. Int. J. Soc. Behav. Educ. Econ. Bus. Ind. Eng. 2016, 10, 3981-3986.

64. Rai, S.; Meschini, M.; Genangeli, S. The Implementation of Drones in the Business Model of Photovoltaic Companies. Master's Thesis, Copenhagen Business School, Frederiksberg, Denmark, 2016.

65. Silver, B.; Mazur, M.; Wiśniewski, A.; Babicz, A. Welcome to the Era of Drone-Powered Solutions: A Valuable Source of New Revenue Streams for Telecoms Operators; Communications Review; PwC: London, UK, 2017.

66. Chu, Y.; Xiao, Q.; Yang, L. Electric Vehicle Business Model Innovation Study from the Perspective of the Energy Internet; IEEE: New York, NY, USA, 2017; ISBN 978-1-5386-1427-3.

67. Shao, L.; Xue, Y.; You, J. A Conceptual Framework for Business Model Innovation: The Case of Electric Vehicles in China. Probl. Ekorozw. 2014, 9, 27-37. 
68. Meenakshisundaram, R.; Shankar, B. Business Model Innovation by Better Place a Green Ecosystem for the Mass Adoption of Electric Cars; Hamschmidt, J., Pirson, M., Eds.; Greenleaf Publishing: West Park, FL, USA, 2011; pp. 292-316, ISBN 978-1-906093-47-1.

69. Tiscini, R.; Testarmata, S.; Ciaburri, M.; Ferrari, E. The Blockchain as a Sustainable Business Model Innovation. Manag. Decis. 2020, 58, 1621-1642. [CrossRef]

70. Guo, B.; Pang, X.; Li, W. The Role of Top Management Team Diversity in Shaping the Performance of Business Model Innovation: A Threshold Effect. Technol. Anal. Strateg. Manag. 2018, 30, 241-253. [CrossRef]

71. Bereznoy, A. Changing Competitive Landscape Through Business Model Innovation: The New Imperative for Corporate Market Strategy. J. Knowl. Econ. 2019, 10, 1362-1383. [CrossRef]

72. Brondoni, S.M.; Zaninotto, E. Ouverture de "The 4th Industrial Revolution. Business Model Innovation \& Global Competition". Symphonya 2018, 2, 1-7. [CrossRef]

73. Desyllas, P.; Sako, M. Profiting from Business Model Innovation: Evidence from Pay-As-You-Drive Auto Insurance. Res. Policy 2013, 42, 101-116. [CrossRef]

74. Ghezzi, A.; Balocco, R.; Rangone, A. How to Get Strategic Planning and Business Model Design Wrong: The Case of a Mobile Technology Provider. Strateg. Chang. 2010, 19, 213-238. [CrossRef]

75. Bashir, M.; Verma, R. Why Business Model Innovation Is the New Competitive Advantage. IUP J. Bus. Strategy 2017, 14, 7-17.

76. Bashir, M.; Verma, R. Internal Factors \& Consequences of Business Model Innovation. Manag. Decis. 2019, 57, 262-290. [CrossRef]

77. Saqib, N.; Satar, M.S. Exploring Business Model Innovation for Competitive Advantage: A Lesson from an Emerging Market. Int. J. Innov. Sci. 2021. ahead-of-print. [CrossRef]

78. Liao, S.; Liu, Z.; Zhang, S. Technology Innovation Ambidexterity, Business Model Ambidexterity, and Firm Performance in Chinese High-Tech Firms. Asian J. Technol. Innov. 2018, 26, 325-345. [CrossRef]

79. Cearley, D.; Burke, B.; Smith, D.; Jones, N.; Chandrasekaran, A.; Lu, C. Top 10 Strategic Technology Trends for 2020; A Gartner Special Report; Gartner: Stamford, CT, USA, 2019.

80. Al-Nimer, M.; Abbadi, S.S.; Al-Omush, A.; Ahmad, H. Risk Management Practices and Firm Performance with a Mediating Role of Business Model Innovation. Observations from Jordan. J. Risk Financ. Manag. 2021, 14, 113. [CrossRef]

81. Christensen, C.M.; Bartman, T.; van Bever, D. The Hard Truth about Business Model Innovation; MIT Press: Cambridge, MA, USA, 2018; pp. 139-164, ISBN 978-0-262-53571-7.

82. Yu, B.; Hao, S.; Wang, Y. Organizational Search and Business Model Innovation: The Moderating Role of Knowledge Inertia. J. Knowl. Manag. 2020, 24, 1705-1718. [CrossRef]

83. Teece, D. Business Models and Dynamic Capabilities. Long Range Plan. 2018, 51, 40-49. [CrossRef]

84. Westerman, G. Your Company Doesn't Need a Digital Strategy. MIT Sloan Manag. Rev. 2018, 59, 116-120.

85. Mikusz, M.; Schaefer, T.; Taraba, T.; Jud, C. Transforming the Connected Car into a Business Model Innovation. In Proceedings of the 2017 IEEE 19th Conference on Business Informatics (CBI), Thessaloniki, Greece, 24-27 July 2017; Loucopoulos, P., Manolopoulos, Y., Pastor, O., Theodoulidis, B., Zdravkovic, J., Eds.; IEEE: New York, NY, USA, 2017; Volume 1, pp. 247-256, ISBN 978-1-5386-3034-1.

86. Ragozzino, R.; Chintakananda, A.; Reuer, J.J. The Use of Quantitative Methodologies in Competitive Strategy Research; Dagnino, G.B., Ed.; Edward Elgar Publishing Ltd.: Cheltenham, UK, 2012; pp. 379-396. ISBN 978-1-84720-044-0.

87. Scandura, T.A.; Williams, E.A. Research Methodology in Management: Current Practices, Trends, and Implications for Future Research. Acad. Manag. J. 2000, 43, 1248-1264. [CrossRef]

88. Henry, G.T. Practical Sampling; Applied Social Research Methods; SAGE Publications, Inc.: Newbury Park, CA, USA, 1990; Volume 21.

89. Saur-Amaral, I.; Soares, R.R.; Proença, J.F. Business Model Innovation: Where Do We Stand? In ISPIM Conference Proceedings, The XXVII ISPIM Innovation Conference-Blending Tomorrow's Innovation Vintage, Porto, Portugal, 19-22 June 2016; The International Society for Professional Innovation Management (ISPIM): Manchester, UK, 2016; pp. 1-23.

90. Palmatier, R.W. Improving Publishing Success at JAMS: Contribution and Positioning. J. Acad. Mark. Sci. 2016, 44, 655-659. [CrossRef]

91. MacKenzie, S.B.; Podsakoff, P.M. Common Method Bias in Marketing: Causes, Mechanisms, and Procedural Remedies. J. Retail. 2012, 88, 542-555. [CrossRef]

92. Audretsch, D.B.; Kuratko, D.F.; Link, A.N. Dynamic Entrepreneurship and Technology-Based Innovation. J. Evol. Econ. 2016, 26, 603-620. [CrossRef] 